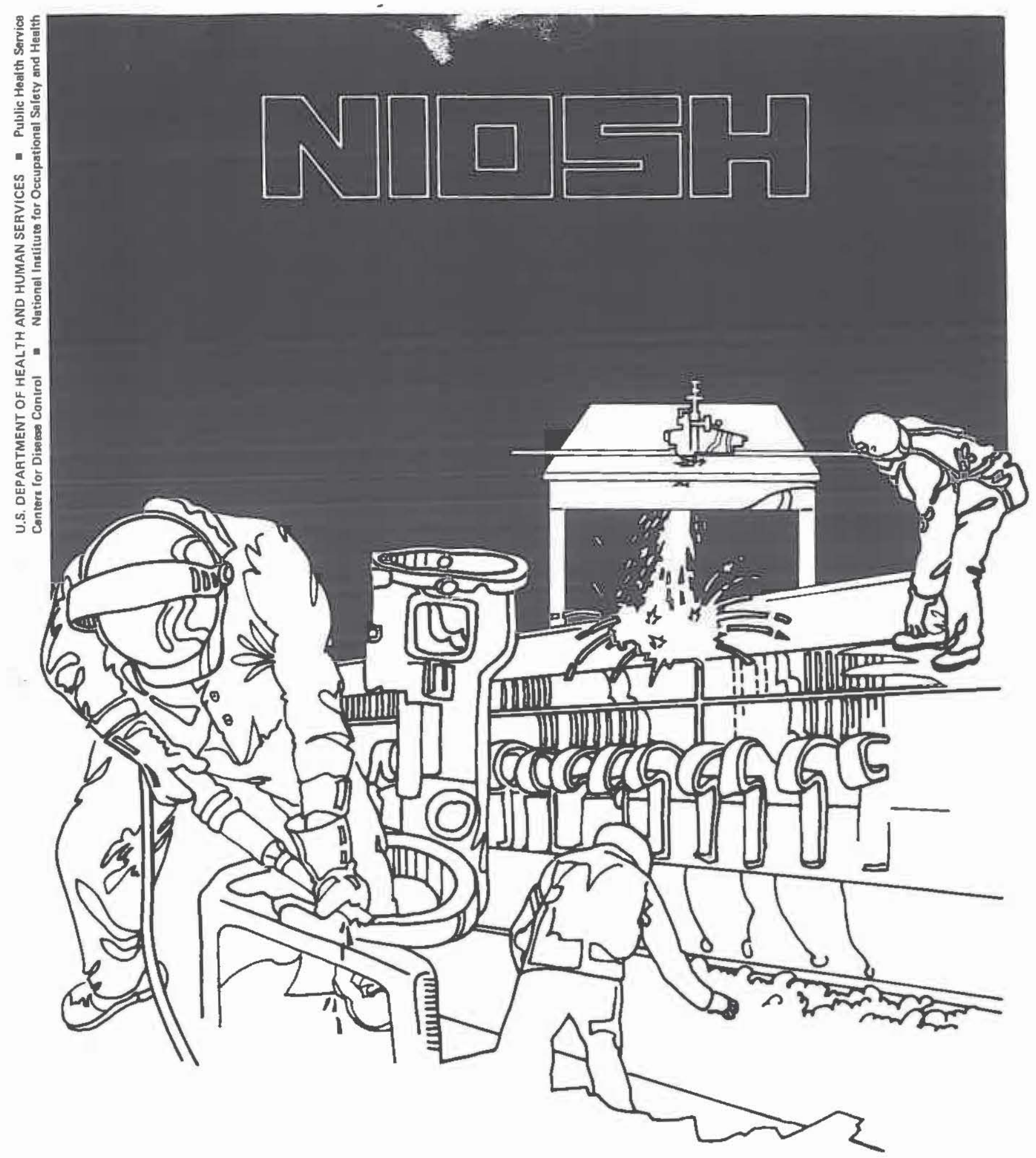

\title{
Health Hazard Evaluatior Report
}

HETA 84-038-1513 KENNECOTT SMELTER HURLEY, NEW MEXICO 
The Hazard Evaluations and Technical Assistance Branch of NIIOSH conducts field investigations of possible health hazards in the workplace. These investigations are conducted under the authority of Section $20(a)(E)$ of the 0ccupational Safety and Health Act of $1970,2 S$ U.S.C. 66S(a)(6) which authorizes the Secretary of Health and Human Services, following a written request from any employer or authorized representative of employees, to determine whether any substance normally found in the place of employment has potentially toxic effects in such concentrations as used or found.

The Hazard Evaluations and Technical Assistance Branch also provides, upon request, medical, nursing, and industrial hygiene technical and consultative assistance (TA) to Federal, state, and $10 \mathrm{ca} 1$ agencies; labor; industry and other groups or individuals to control occupational health hazards and to prevent related trauma and disease.

Mention of company names or products does not constitute endorsement by the National Institute for Occupational Safety and Health. 
HETA 84-038-1513

OCTOBER 1984

KENNECOTT SMELTER

HURLEY, NEW MEXICO
NIOSH INVESTIGATORS:

Bobby J. Gunter, Ph.D.

Paul J. Seligman, M.D.

I. SUMMARY

From January 9 th through 12th, 1984, investigators from the National Institute for Occupational Safety and Health (NIOSH) and the New Mexico Health Department visited the Chino Mines Division of the Kennecott Corporation, Hurley, New Mexico. The request was precipitated by the death of a 37 year old machine operator in the smelter from lung cancer.

An environmental survey with personal sampling for arsenic, cadmium, copper, lead, sulfuric acid, sulfur dioxide, crystalline silica and total particulate and a review of the company medical surveillance program and 66 company medical records of current smelter employees was accomplished. Medical interviews were conducted on 19 employees. Nineteen samples for blood lead and 48 samples for urine arsenic were collected from smelter workers. The widow of the deceased machine operator was interviewed at which time documents relating to his hospital course and subsequent autopsy were obtained.

All environmental breathing zone and general room air samples for arsenic were below the laboratory detection level of $0.01 \mathrm{mg} / \mathrm{sample}$. Cadmium $\left(0.01 \mathrm{mg} / \mathrm{m}^{3}\right)$ was found in one of fifteen air samples. NIOSH recommends that exposures to cadmium be maintained below $0.04 \mathrm{mg} / \mathrm{m}^{3}$ based on a 10 hour day 40 hour work week. Airborne copper concentrations in 15 air samples ranged from $0.04 \mathrm{mg} / \mathrm{m}^{3}$ to $0.80 \mathrm{mg} / \mathrm{m}^{3}$ (average of 0.24 $\mathrm{mg} / \mathrm{m}^{3}$ ) The evaluation criteria is $1 \mathrm{mg} / \mathrm{m}^{3}$. Lead was found in 3 of the 15 air samples at levels of $0.006,0.006$, and $0.06 \mathrm{mg} / \mathrm{m}^{3}$. Only one sample exceeded the evaluation criteria of $0.05 \mathrm{mg} / \mathrm{m}^{3}$. All workers monitored for arsenic, cadmium, copper and lead were wearing adequate respiratory protection.

Seven breathing zone air samples for sulfur dioxide $\left(\mathrm{SO}_{2}\right)$ were collected. None of the seven exceeded the OSHA standard of $13 \mathrm{mg} / \mathrm{m}^{3}$. Six of the seven samples exceeded the NIOSH recommended level of $1.3 \mathrm{mg} / \mathrm{M}^{3}$. Three sulfuric acid $\left(\mathrm{H}_{2} \mathrm{SO}_{4}\right)$ general area samples were col- lected in the acid plant. Levels of the $\mathrm{H}_{2} \mathrm{SO}_{4}$ were $0.15,0.23$ and $0.24 \mathrm{mg} / \mathrm{m}^{3}$ which were within the evaluation criteria of $1.0 \mathrm{mg} / \mathrm{m}^{3}$. Levels of total particulate, and crystalline silica were all below the evaluation criteria. In all areas of the smelter, proper respiratory protection was worn and adequate training was provided.

On the basis of environmental and medical monitoring, NIOSH concluded that there was a potential health hazard to sulfur dioxide and lead during this evaluation. Adequate respiratory protection was worn as illustrated by medical monitoring data which showed low blood lead levels, no elevated urine arsenic levels and no symptoms typical of acid gas exposures.

KEYWORDS: SIC 3331, copper, arsenic, lead, cadmium, cancer, sulfur dioxide 
Health Hazard Evaluation Report No. 84-038, Page 2

\section{INTRODUCTION}

In November 1983 the National Institute for Occupational Safety and Health (NIOSH) received a request from the United Steelworkers of America Carlsbad, New Mexico to evaluate potential health hazards in a copper smelter in Hurley, New Mexico. The request was precipitated by the recent death of a 37 year old machine operator in the smelter from lung cancer. The environmental and medical evaluations were conducted the week of January 9, 1984.

\section{BACKGROUND}

This smelter receives a concentrated copper ore from a nearby copper mine. The ore is processed in the Hurley smelter and the finished product is very near 100 percent copper. The smelter had a sulfuric acid plant.

During the smelting of Copper ore, it is possible for workers to receive exposures to various metals such as: copper, arsenic, lead, and cadmium. Levels of sulfur dioxide often exceed evaluation criteria. Other exposures may include crystalline silica and total particulate.

After discussion of this evaluation with management and union, it was decided that the medical and environmental investigation would include: the convertor, reverberatory furnaces, sulfuric acid plant, mold making area and the refinery.

\section{ENVIRONMENTAL DESIGN AND METHODS}

Breathing zone and general room air samples were taken in the reverberatory furnace area, the convertor area, and the refinery area for arsenic, cadmium, copper and lead. Cadmium, copper and lead were collected on 37 $\mathrm{mm}$ filters using vacuum pumps operating at 1.5 liters per minute and were analyzed by atomic absorption spectrometry. Arsenic was done separately according to a modified NIOSH Method, P \& Cam No. 173.

Sulfur Dioxide samples were collected on membrane filters using pumps operated at 1.5 liters per minute and analyzed according to NIOSH Method P \& Cam No. 268.

Sulfuric acid was collected on silica gel tubes using vacuum pumps at 200 cC minute and analyzed by NIOSH Method No. P \& Cam 339.

Total weight and crystalline silica samples were taken on $37 \mathrm{~mm}$ membrane filters using pumps operated 1.5 liters per minute and analyzed by NIOSH Method P \& Cam No. 259.

\section{v. MEDICAL METHODS}

Sixty-six medical records of current employees at the smelter were reviewed. These employees work as punchers, skimmer/convertors, trippentmen, tappers, feedermen, laborers/boilers, smelter equipment operators, and electrostatic precipitator operators/helpers.

A11 66 employees had chest X-ray (CXR) reports on record. Ninety-one percent of these X-ray examinations were performed between 1981 and 1983. 
Health Hazard Evaluation Report №. 84-038, Page 3

Sixty-four of 66 CXR reports were noted to be within nomal limits. Of the two abnormal CXR's, one was noted to have a single calcific nodule, the other was consistent with chronic obstructive pulmonary disease.

Forty-eight random post-shift spot urines for arsenic were obtained during the visit. Samples were provided by workers starting on Tuesday after at least two full work-shifts had been completed during the week. Workers were instructed to wash their hands thoroughly prior to providing the sample. ESA, a licensed certified contract laboratory, performed the analysis using an anodic stripping voltametry method.

Urine arsenic levels are reported as $\mathrm{ug} / \mathrm{L}$ and $\mathrm{ug} / \mathrm{g}$ creatinine. Expressing the values as ug/g creatinine normalizes individual differences in excretion rates and urinary output. The 1 imit of $100 \mathrm{ug} / \mathrm{g}$ creatinine cited above is used to indicate excess arsenic exposure.

Nineteen samples for blood lead were obtained.

VI. EVALUATION CRITERIA

As a guide to the evaluation of the hazards posed by workplace exposures, NIOSH field staff employ environmental evaluation criteria for assessment of a number of chemical and physical agents. These criteria are intended to suggest levels of exposure to which most workers may be exposed up to 10 hours per day, 40 hours per week for a working lifetime without experiencing adverse health effects. It is however, important to note that not all workers will be protected from adverse health effects if their exposures are maintained below these levels. A small percentage may experience adverse health effects because of individual susceptibility, a preexisting medical condition, and/or a hypersensitivity (allergy).

In addition, some hazardous substances may act in combination with other workplace exposures, the general environment, or with medications or personal habits of the worker to produce health effects even if the occupational exposures are controlled at the level set by the evaluation criterion. These combined effects are often not considered in the evaluation criteria. Also, some substances are absorbed by direct contact with the skin and mucous membranes, and thus potentially increase the overall exposure. Finally, evaluation criteria may change over the years as new information on the toxic effects of an agent become available.

The primary sources of envirommental evaluation criteria for the workplace are: 1) NIOSH Criteria Documents and recommendations, 2) the American Conference of Governmental Industrial Hygienists' (ACGIH) Threshold Limit Values (TLV's), and 3) the U.S. Department of Labor (OSHA) occupational health standards. Often, the NIOSH recommendations and ACGIH TLV's are lower than the corresponding OSHA standards. Both NIOSH recommendations and ACGIH TLV's usually are based on more recent information than are the OSHA standards. The OSHA standards also may be required to take into account the feasibility of controlling exposures in various industries where the agents are used; the NIOSH-recommended standards, by contrast, are based primarily on concerns relating to the prevention of occupational disease. In evaluating the exposure levels and the recomendations for reducing these levels found in this report, it should be noted that indus- 
Hea 1th Hazard Evaluation Report No. 84-038, Page 4

try is legally required to meet only those levels specified by an OSHA standard.

A time-weighted average (TWA) exposure refers to the average airborne concentration of a substance during a normal 8- to 10-hour workday. Some substances have recommended short-term exposure limits or ceiling values which are intended to supplement the TWA where there are recognized toxic effects from high short-term exposures.

\author{
Permissible Exposure Limits \\ 8-Hour Time-Weighted \\ Exposure Basis $\mathrm{mg} / \mathrm{M}^{3}$
}

Arsenic
Cadmium
Copper
Lead
Sulfuric Acid
Sulfur Dioxide
Crystalline Silica

Total particulate

$\begin{array}{ll}0.01 & \text { (OSHA) } \\ 0.04 & \text { (NIOSH) } \\ 1.0 & \text { (NIOSH, OSHA) } \\ 0.05 & \text { (NIOSH, OSHA) } \\ 1.0 & \text { (NIOSH, OSHA) } \\ 1.3 & \text { (NIOSH) } \\ & 10 \mathrm{mg} / \mathrm{M}^{3}\end{array}$

\% Respirable quartz+2

10.0 (ACGIH)

VII. TOXICOLOGICAL

Arsenic -- NIOSH has recommended that airborne concentrations of inorganic arsenic be controlled to prevent exposures in excess of $0.002 \mathrm{mg} / \mathrm{M}^{3}$. For the purposes of the recommended standard, arsenic is defined as elemental arsenic and all of its inorganic compounds. To determine the extent of worker exposures, a 15 minute sampling period is advised for avoidance of spurious sampling results produced by natural "background" concentrations (not to be confused with the traditional "ceiling" designation occasionally assigned to some of the more toxic chemicals which require 15 minute exposure determinations). The recommended standard was designed to protect workers fror the possible development of lymphatic and respiratory arsenic-related cancer. This relationship has been suggested by numerous studies of working populations.

The OSHA standard for inorganic arsenic is $.01 \mathrm{mg} / \mathrm{m}^{3}$, as averaged over an 8 hour work shift.

Studies of arsenic exposure related to copper smelting have focused on concerns over lung cancer. Excess mortality from lung cancer has been described in several populations of copper smelter workers exposed to arsenic trioxide. 1,2,3,4,5,6 Exposures in smelters are multiple raising the issue of whether arsenic alone is a lung carcinogen or whether concomitant exposure to sulfur dioxide or other dusts is necessary for the subsequent development of lung cancer. However, studies of arsenic-exposed pesticide workers in the U.S. and abroad, with no sulphur dioxide exposure, have consistently demonstrated excess lung cancer mortality. Increasing exposure to arsenic-containing materials with increasing duration of employment has been shown to correlate directly with an increasing trend of excess lung cancer. 
Health Hazard Evaluation Report No. 84-038, Page 5

Chronic excess exposure to arsenic in drinking water is reputed to produce peripheral vascular disease, with the most severe exposures leading to gangrene of the extremities. There is no evidence at present to indicate that arsenic exposure is a risk factor in the development of cardiovascular disease.

Arsenic is widely distributed in nature, and everyone is exposed to this metal. Human exposures occur via seafood ingestion, contact with arsenical pesticides, and inhalation of arsenic-containing particulates. Inhalation of arsenic-contaminated dust is the primary route of occupational exposure. Ingestion of seafood is the principal source of background population exposure to arsenic. Major occupational exposure occurs at smelting operations. Once assimilated, arsenic is distributed throughout the body. Arsenic seems to accumulate in muscle tissue. Arsenic in blood is evenly distributed between the plasma and erythrocytes. Ninety percent of assimilated arsenic will be excreted via the kidney within six days. Urine arsenic concentration appears to be the best indicator of recent exposure with the biologic half-life of arsenic trioxide being 1-2 days. While 24-hour collections of urine are optimal for determining arsenic exposure, random spot-urine collections, as were done here, give adequate indication of arsenic absorption. Arsenic III, one of the most toxic forms of arsenic, has a biologic half-1ife of $1-2$ days. $7,8,9$

Given the strong dose-related association between exposure to arsenic and lung cancer, it is difficult to determine a level of exposure that is absolutely safe. Ingestion of $200 \mathrm{mg}$ of arsenic is considered a lethal dose. 9 Humans exposed to arsenic concentrations of $500 \mathrm{ug} / \mathrm{m}^{3}$ will eventually have a urine concentration of $1000 \mathrm{ug} / \mathrm{L} .9$ Exposure to 50 $\mathrm{ug} / \mathrm{m}^{3}$ will produce urine arsenic levels of $170 \mathrm{ug} / \mathrm{L} .{ }^{8}$ Ingestion of seafood may raise the arsenic levels to 200-1700 ug/L within four hours. ${ }^{2}$ Urine arsenic levels of 10-300 ug/L are reported for unexposed populations. 9 For those who have not ingested seafood, a limit of 100 mg arsenic per gram of creatinine in the urine 8 has been suggested as an indicator of "safe" exposure to occupational arsenic. This value is used in analyzing the urine data presented in this report.

Cadmium -- Cadmium is a toxic heavy metal which may enter the body either by ingestion (swallowing) or by inhalation (breathing) of cadmium metal or oxide. Once absorbed into the body, cadmium accumulates in organs throughout the body, but major depositions occur in the liver and kidneys. Acute inhalation exposure to high levels of cadmium can cause pneumonia or pulmonary edema, as well as liver and kidney damage.10 Chronic exposure may lead to emphysema of the lungs and kidney disease, or cancer of the prostrate. 11 There is also limited evidence that occupational cadmium exposure may be associated with lung cancer.

NIOSH recommends that worker exposures to cadmium dust or fume be limited to not more than $200 \mathrm{ug} / \mathrm{m}^{3}$ during a 15-minute ceiling period or to a threshold limit value (TLV) or not more than $40 \mathrm{ug} / \mathrm{m}^{3}$, as a timeweighted average (TWA) over a 10-hour shift. The Occupational Safety and Health Administration (OSHA) standard for cadmium dust exposure is 200 $\mathrm{ug} / \mathrm{m}^{3}$, and for cadmium fume exposure $100 \mathrm{ug} / \mathrm{m}^{3}$, using an 8-hour TWA for each. 
Health Hazard Evaluation Report No. 84-038, Page 6

Copper Mist, Dust, and Fume -- Inhalation of dusts and mists of copper and copper salts results in irritation of the upper respiratory tract and, occasionally, ulceration and perforation of the nasal septum. Metal fume fever, a 24-28 hour illness characterized by chills, fever, aching muscles, dryness in the mouth and throat, and headache, may occur due to exposure to metaloxide fume rather than copper dust.

Copper particles embedded in the eye result in a pronounced foreign body reaction, with characteristic discoloration of ocular tissue.

Allergic contact dermatitis due to copper, although rare, has been reported.

Lead -- Inhalation (breathing) of lead dust and fume is the major route of Tead exposure in industry. A secondary source of exposure may be from ingestion (swallowing) of lead dust deposited on food, cigarettes, or other objects. Once absorbed, lead is excreted from the body very slow1y. Absorbed lead can damage the kidneys, peripheral and central nervous systems, and the blood forming organs. Chronic lead exposure is associated with infertility and with fetal damage in pregnant women.

Blood lead levels below $40 \mathrm{ug} /$ deciliter whole blood are considered to be normal levels which may result from daily environmental exposure. The new Occupational Safety and Health Administration (OSHA) standard for lead in air is $50 \mathrm{ug} / \mathrm{m}^{3}$ calculated as an 8-hour time-weighted average for daily exposure. 12 The standard also dictates that workers with blood lead levels greater than $60 \mathrm{ug} /$ deciliter must be immediately removed from further lead exposure and, in some circumstances, workers with lead levels of less than $60 \mathrm{ug} /$ deciliter must also be removed. Removed workers have protection for wage, benefits, and seniority for up to 18 months until their blood levels decline to below $40110 \mathrm{~g}$ whole blood. They can then return to lead exposure areas.

Sulfur Dioxide -- Sulfur dioxide $\left(\mathrm{SO}_{2}\right)$ is a gas which produces eye and respiratory irritation. Bronchoconstriction is observed probably as a result of an irritant-induced stimulation of the airway walls. Asthmatics may be particulariy sensitive to bronchoconstriction from $\mathrm{SO}_{2}$ exposure.

Acute decrements in forced vital capacity (FVC) and forced expiratory volume in one second $\left(F E V_{1}\right)$ have been observed in smelter workers after an 8-hour shift following exposure to $\mathrm{SO}_{2}$. Whether chronic loss of 1 ung function following long-term $\mathrm{SO}_{2}$ exposure occurs is controversial. The current OSHA standard establishes a permissible exposure limit (PEL) of 5 ppm over an 8-hour time-weighted average (TWA). In 1980, the American Conference of Governmental Hygienists recommended lowering the PEL to 2 ppm because it can cause bronchoconstriction and a temporary decrease in pulmonary function. ACGIH also recommends a 15-minute short-term exposure limit of $5 \mathrm{ppm}$. NIOSH recommends a 10-hour TWA exposure limit of $0.5 \mathrm{ppm}$ based on studies indicating chronic respiratory disease among workers exposed to 1-4 ppm of sulfur dioxide.

There are no reports in the medical literature describing an association between the potential exposures in the smelting industry and retroperitoneal fibrosis. Most cases of this condition arise without a known cause, with certain medications containing methysergide derivatives 
Health Hazard Evaluation Report No. 84-038, Page 7

(Sansert) for relief of migraine headaches having been implicated as an etiologic factor.

Crystalline Silical,3 -- Crystalline silica, usually referred to as free silica, is defined as silicon dioxide $\left(\mathrm{SiO}_{2}\right)$ molecules arranged in a fixed pattern as opposed to a nonperiodic, random molecular arrangement defined as amorphous silica. The three most common crystalline forms of free silica encountered in industry are quartz tridymite, and cristabolite, with quartz being by far the most common. NIOSH, in its recommendations for a free silica standard, has proposed that exposures to all forms of free silica be controlled so that no worker is exposed to respirable airborne concentrations greater than $0.05 \mathrm{mg} / \mathrm{M}^{3}$, as averaged over a 10 hour working day, 40 hour work week. This recommendation was designed to protect workers from silicosis, a pneumoconiosis due to the inhalation of silicon dioxide-containing dust. Exposures to free silica greater than one-half the recommended standard or "acting level" should initiate adherence to the environmental, medical, labeling, recordkeeping, and worker protection guidelines as contained in Chapter I of the NIOSH criteria document, "Occupational Exposure to Crystalline Silica." The current federal OSHA standard for respirable free silica exposure is an 8 hour time-weighted average based upon the 1968 ACGIH TLV formulas of $10 \mathrm{mg} / \mathrm{M}^{3}$ divided by the percent $\mathrm{SiO}_{2}$ plus $2\left(10 \mathrm{mg} / \mathrm{M}^{3} / \% \mathrm{SiO}_{2}+2\right)$ for respirable quartz. One-half this amount was established as the limit for cristabolite and tridymite. As can be seen from the calculation, the OSHA regulation is based on the percentage of free silica contained in the respirable particulate exposure whereas the NIOSH recommended standard applies directly to the airborne concentrations of respirable free silica.

Respirable Particulate -- Exposures to total particulate may cause unpleasant deposits in the eyes and nasal passages. Some respirable problems due to deposition in the lungs may also occur.

Sulfuric Acid -- Sulfuric acid $\left(\mathrm{H}_{2} \mathrm{SO}_{4}\right)$ can affect the body if it is inhaled, ingested, or comes in contact with the skin. Sulfuric acid may cause irritation of the eyes, nose, and throat. Breathing in of the mist or vapor may cause teeth erosion, soreness in the mouth and difficulty in breathing. Splashes in the eyes or on theskin will cause severe skin burns. (Chronic exposures to sulfuric acid may lead to dermatitis, eye irritation, and inflammation of the nose, throat and bronchial tubes. 13

VIII. ENVIRONMENTAL RESULTS

Fifteen breathing zone air samples were collected on workers in all areas of the smelter where exposures could occur. These samples were collected for a minimum of 7.5 hours. Arsenic was not found in any of the samples (detection levels $0.01 \mathrm{mg} / \mathrm{sample}$ ). Cadmium was found in one sample at a level of $0.01 \mathrm{mg} / \mathrm{m}^{3}$ (evaluation criteria is $0.04 \mathrm{mg} / \mathrm{m}^{3}$ based on a 10 hour work day.) Copper was found in all samples with a high of $0 . \overline{80}$ $\mathrm{mg} / \mathrm{m}^{3}$ and a low of $0.04 \mathrm{mg} / \mathrm{m}^{3}$ and an average for the 15 analyses of $0.24 \mathrm{~m}^{3}$ (the evaluation criteria is $1 \mathrm{mg} / \mathrm{m}^{3}$ ). Three out of 15 analyses showed lead in detectable amounts of $0.0006,0.006$, and $0.06 \mathrm{mg} / \mathrm{m}^{3}$. Two of the three were below the evaluation criteria of $0.05 \mathrm{mg} / \mathrm{m}^{3}$.

Seven breathing zone air samples for sulfur dioxide were collected on workers in the reverberatory furnace and converter areas. Six out of 
seven exceeded the evaluation criteria of $1.3 \mathrm{mg} / \mathrm{M}^{3}$. The average concentration was $5.3 \mathrm{mg} / \mathrm{m}^{3}$.

Three sulfuric acid general area samples were collected in the acid plant. The levels were $0.15,0.23$ and 0.24 , well within the evaluation criteria of $1.0 \mathrm{mg} / \mathrm{m}^{3}$. Six breathing zone air samples were taken for total particulate and crystalline silica. Levels of total particulate ranged from 0.25 to $1.25 \mathrm{mg} / \mathrm{m}^{3}$, the average was $0.41 \mathrm{mg} / \mathrm{m}^{3}$. All concentrations were below the evaluation criteria of $10 \mathrm{mg} / \mathrm{m}^{3}$. Crystalline silica (Quartz only) was found in two samples $0.007 \mathrm{mg} / \mathrm{m}^{3}$ and 0.04 $\mathrm{mg} / \mathrm{m}^{3}$ (welt below the evaluation criteria of $0.3 \mathrm{mg} / \mathrm{m}^{3}$ ). Results of environmental sampling may be reviewed in Tables 1-5.

IX. MEDICAL MONITORING AND RESULTS

A. Sputum Cytologies

Sputum cytologies were reported in 42 of 66 records. Of these, 25 were negative, 14 were reported as showing squamous metaplasia, and three samples did not have sufficient quantities for analysis. Squamous metaplasia is considered to be a benign condition usually related to smoking or some other bronchial irritant. Although benign, metaplastic cells are considered a precursor to the development of squamous cell carcinoma of the lung. This condition usually disappears with the cessation of smoking or other irritation. Smoking histories were noted for most of the cytologies reporting squamous metaplasia.

Table $V$ summarizes the medical record data by job category for chest $X$-rays, PFT's, and sputum cytology.

B. Pulmonary Function Tests

A11 66 records contained pulmonary function test (PFT) reports. Over those years for which PFT reports were available, no significant decrements with time in individual PFTs done serialiy were observed. However, considering that chronic respiratory disease from an exposure to sulfur dioxide may take years to develop, it is impossible using this limited data to draw any conclusions about the future health effects from current $\mathrm{SO}_{2}$ exposures, particularly in light of the elevated $\mathrm{SO}_{2}$ levels (greater than $5 \mathrm{mg} / \mathrm{M}^{3}$ ) reported in the environmental section, Using the criteria of a forced vital capacity (FVC) or a forced expiratory volume after one second $\left(F E V_{\eta}\right)$ of greater than $70 \%$ predicted for age and height, two of the 66 PFT's were abnormal. One of these individuals gave a history of $120+$ packyears of cigarette smoking; the other had the CXR consistent with COPD. PFTs evaluated by job category revealed no significant differences for jobs where there were enough employees to form a basis for comparison.

C. Lead

Blood lead levels were reported in 49 of 66 records reviewed. The range of Tevels was $0-24$ with a mean of $10.6 \pm 5.1 \mathrm{ug} / \mathrm{dl}$. Levels 
greater than $40 \mathrm{ug} / \mathrm{d} 1$ usually indicates excessive exposure to lead. No level exceeded the value. Company data compared favorably with lead levels obtained on 19 workers presented in the next section.

Blood lead values ranged from less than 5 to $15 \mathrm{ug} / \mathrm{dl}$ with a mean of $6.0 \pm 3.7 \mathrm{ug} / \mathrm{dl}$ and a median of $6.0 \mathrm{ug} / \mathrm{dl}$. All lead values were well below $40 \mathrm{ug} / \mathrm{dl}$. Lead values above $40 \mathrm{ug} / \mathrm{dl}$ are indicative of excess exposure to lead. Our data indicate no recent excessive exposure to lead.

Zinc protoporphyrin (ZnPP) levels, a measure of the effect of lead on the function of red blood cells, were noted in 16 of 66 charts. The levels ranged from 0-62 with a mean of $21.2+19.6 \mathrm{ug} / \mathrm{d} 1$. Levels greater than $50 \mathrm{ug} / \mathrm{dl}$ are usually indicative of excessive exposure to lead. Two of the values minimaliy exceeded the $50 \mathrm{ug} / \mathrm{dl} 1 \mathrm{imit}$. Both of these individuals were employed as skimmer/convertors. However, in light of their normal lead levels, it is probable that the ZnPP elevation was not related to excessive exposure to lead on the job.

\section{Arsenic}

When corrected for urinary creatinine, the geometric mean for the forty eight workers tested for arsenic was $5.4 \mathrm{ug} / \mathrm{g}$ creatinine with 95\% confidence limits of 1.3-9.5. The distribution of urine arsenic levels is presented in Figure I (located in the appendix) with a range from below the level of detection to $72.5 \mathrm{ug} / \mathrm{g}$ and a median of $5.3 \mathrm{ug} / \mathrm{g}$. The one sample reported at 72.5 was from a worker who gave a history of frequent fish ingestion, probably accounting for this outlying value, though still within the range considered "safe" for industrial exposure.

All urine arsenic values were below those levels suggested as indicators of excess exposure to arsenic.

In addition to the summary of the urine arsenic data, this population of smelter workers was compared to community data that exist in the literature. 14 Comparing the urine arsenic levels in $\mathrm{ug} / \mathrm{L}$ with other populations, there is no significant differences between the smelter workers reported here and populations of children living in Hurley, in other copper-smelter towns, or in non-smelter towns. Table VI below summarizes this information. 
Health Hazard Evaluation Report No. 84-038, Page 10

\section{TABLE VI}

Urine arsenic levels (ug/L) in smelter workers compared with children

in Hurley, N.M., other copper smelter towns, and in non-copper smelter towns

\# of samples Geometric $\frac{95 \% \text { confi }}{\text { Mean Median }}$ Elevated T-Test

\begin{tabular}{|c|c|c|c|c|c|}
\hline Smelter workers & $48\left(7^{\star}\right)$ & 9.7 & $0-19.8$ & 9.0 & 6 \\
\hline $\begin{array}{l}\text { Children } \\
\text { Hurley, N.M. }\end{array}$ & $57\left(3^{\star}\right)$ & 6.9 & $5.2-9.2$ & 6.6 & 2 \\
\hline $\begin{array}{l}\text { Children -copper } \\
\text { smelting towns }\end{array}$ & $712(13 *)$ & 18.7 & $17.7-20.5$ & 19.8 & 146 \\
\hline $\begin{array}{l}\text { Children - } \\
\text { non-copper } \\
\text { smelting towns }\end{array}$ & $193(29 *)$ & 5.8 & $4.7-7.0$ & 7.,3 & 9 \\
\hline
\end{tabular}

Urine arsenic levels were compared between job categories. No statistically significant differences were observed comparing mean urine arsenic levels using a student t-test for analysis.

No correlation between exposure data and urinary arsenic levels could be made because of the 1 ack of detectable arsenic in the environmental samples.

E. Questionnaire Survey Results

Nineteen workers completed an administered questionnaire designed to elicit symptoms of respiratory disease, occupational history, and pertinent medical history related to the respiratory system. Questions were designed from the respiratory questionnaire published by the American Thoracic Society. The demographics of the population surveyed and the results of the questionnaire are listed in Table VII. 


\section{TABLE VII}

Respiratory Symptoms Among Smelter Workers

Kennecott Corporation

Hurley, New Mexico

$(\mathrm{N}=19)$

Age $-34.9 \pm 10.0$ years; range $29-60$

Sex - 19/19 male

Race - Hispanic 10/19

White $8 / 19$

Native American 1/19

Symptom

Cough

Phlegm

Wheezing

Breathlessness

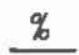

$21 \%$

$32 \%$

$16 \%$

$38 \%$
\% significant

$11 \% *$

$11 \% *$

5\%\#

$5 \%$

* for most days greater than 3 consecutive months or more per year

\# gets worse during the work-day with relief on the weekends

e shortness of breath after walking 100 yards

Three of four individuals who noted occasional cough and one noting significant cough had elevated sulfur dioxide exposures. Two of the four individuals are current smokers.

Al] three workers with attacks of wheezing gave histories of onset during adulthood concurrent with employment at the smelter. Only two of the job categories of these three workers were sampled for $\mathrm{SO}_{2}$ with both samples demonstrating elevated levels. Two of the three workers with wheezing are current smokers.

No respiratory symptoms were reported among the four employees of the acid plant interviewed.

Ten of 19 interviewed were current cigarette smokers.

F. Cancer Mortality Study

In 1976, a study of deaths from respiratory cancer among employees, former employees, and retirees of the Kennecott Corporation was undertaken by the University of California, San Francisco, School of Medicine. The study was performed at the request of Kennecott, with employee records furnished by the corporation. 
Reviewed were 2010 death certificates covering the years 1950-1969. For employees working five years or longer at the Chino-Mines Division (CMD), excess deaths from cancer of the respiratory tract were noted in the three areas of the operation studied; the smelter, mine, and concentrator. Table VIII sumarizes the data and proportionate mortality ratios (PMR) presented by Milby and Hine

TABLE VIII

Respiratory Tract Cancer Mortality Among Employees
Working Five Years or Longer
By Work Site
$(1950-1969)$

$\frac{\text { Deaths from malignant neopl asm }}{\text { of respiratory tract }}$

A11 deaths Expected PMR

CMD Smelter

3

33

0.33

9.1

CMD Mine

8

143

116

1.43

1.18

*Expected \# of deaths from lung cancer was calculated from the number of deaths from respiratory cancer divided by the PMR, i.e. $3 / 9.1=$ 0.33 expected in a sample of 33 total deaths.

Using a table of cumulative poison distributions, the $p$ value for the PMR of 9.1 is less than 0.01 .

No data related to other causes of death were presented in this study. To our knowledge, there was no adjustment of the data for antecedent smoking habits or age. There is no way to assess the completeness of the reporting of deaths. Because PMR's are influenced by excesses or the absence of deaths in other disease categories, it is difficult to comment on the significance of the data presented in Table VIII. The three areas at the CMD surveyed during 1950-69 appear to demonstrate excess deaths from respiratory cancers.

Kennecott Corp. is the major employer in Grant County, New Mexico. While not the most sensitive method for determining excess deaths from any cause due to occupation, no evidence of a deviation in death rates from lung cancer compared to the state of New Mexico was observed in Grant County from 1950 to 1978. Looking at county-wide statistics assumes that the employees, former employees, and retirees of Kennecott resided in Grant County at the time of death, which is frequently not the case. The adjacent counties of Luna, Hidalgo, and Sierra also did not demonstrate excess lung cancer deaths. Table IX summarizes data for Grant County and the state of New Mexico. 


\title{
TABLE IX
}

\author{
Cancers of Trachea, Bronchus and Lung \\ (including Pleura) \\ 1950-1978*
}

\begin{tabular}{|c|c|c|c|c|c|c|}
\hline & \multicolumn{2}{|c|}{ 1950-59 } & \multicolumn{2}{|c|}{$1960-1969$} & \multicolumn{2}{|c|}{$\begin{array}{l}\text { 1970-78 } \\
\text { (excluding '72) }\end{array}$} \\
\hline & DEATHS & $\underline{\text { RATE }}^{* \star *}$ & DEATHS & RATE & DEATHS & RATE \\
\hline White** males-Grant, CO & 14 & 17.4 & 27 & 32.3 & 31 & 37.5 \\
\hline White males-New Mexico & 453 & 17.6 & 956 & 29.0 & 1420 & 42.2 \\
\hline White females-Grant, co & 7 & 10.9 & 11 & 15.6 & 21 & 27.6 \\
\hline White females-New Mexico & 129 & 6.1 & 242 & 8.0 & 575 & 17.4 \\
\hline Non-white males-Grant co & - & - & 1 & 127.9 & - & - \\
\hline Non-white males-New Mexico & 10 & 4.5 & 25 & 8.1 & 63 & 19.8 \\
\hline Non-white females-Grant, co & - & - & - & - & - & - \\
\hline $\begin{array}{l}\text { Non-white females-New Mexico } \\
\star \text { From the National Center } \\
\star \star \text { White includes individual } \\
\star \star \star \text { Rates are per } 100,000 \text { pop }\end{array}$ & $\begin{array}{l}\text { o } 2 \\
\text { for Hea } \\
\text { ls of Me } \\
\text { pulation }\end{array}$ & $\begin{array}{l}1.0 \\
\text { th Statis } \\
\text { ican and }\end{array}$ & $\begin{array}{l}9 \\
\text { cs (NCHS } \\
\text { erto Ric }\end{array}$ & 3.5 & 10 & 3.4 \\
\hline DISCUSSION ANO CONCL & LUS IONS & & & & & \\
\hline
\end{tabular}

No evidence of exposures exceeding the OSHA arsenic and lead standards was noted. Company medical records appeared current and generally complete in compliance with standards. The high prevalence of squamous metaplasia on sputum cytologies is of concern because of its possible significance as a precursor of cellular changes leading to squamous cell carcinoma of the lung. While no data exist to indicate the rate at which individuals with squamous metaplasia on sputum cytology go on to develop lung cancer, it is prudent clinical practice to strongly encourage smelter workers with these cytologic changes to stop smoking, particularly given the other potential risk factors for cancer in their work environment.

The OSHA standard requires CXR's annually for employees exposed above the action level $\left(5 \mathrm{ug} / \mathrm{m}^{3}\right)$ for at least 30 days per year, or who have greater than 10 years of combined employment with exposures greater than the action level for at least 30 days per year. The levels of environmental arsenic reported are below the laboratory limit of detection. Given the very low levels of arsenic, the medical monitoring program should clearly establish who should receive annual chest $X$-rays.

Given the elevated exposures to sulfur dioxide, continued use of the acid-gas respirators should be enforced. This facility was providing a 
Health Hazard Evaluation Report No. 84-038, Page 14

good respiratory protection program. In addition, annual pulmonary function tests done by a qualified $1 \mathrm{ab}$ for those exposed to sulfur dioxide along with records organized so as to note any loss of vital capacity or flow rate should be maintained.

Despite low exposure to arsenic at the Hurley smelter, excess lung cancer has been frequently described in copper smelters: The study commissioned by Kennecott cited here does not provide enough information to state whether or not workers at the Chino Mines Division are at increased risk for the development of lung cancer. Clearly, exposures to all possible carcinogens should be reduced to an absolute minimum.

X. RECOMMENDATIONS:

1. Continued efforts to improve the respiratory program. Encourage workers to shave prior to their tour of work.

2. Given the high rate of squamous metaplasia on sputum cytologies noted in the review of medical records, both management and union should make efforts to help workers understand the significance of this medical finding. In particular, workers should know that this pathologic change is a potential precursor to the development of lung cancer, and that it is most frequently associated with cigarette smoking. Furthermore, given the known respiratory carcinogenic potential of arsenic exposure, other lung cancer causing agents should be eliminated wherever possible. Programs and/or incentives to cease smoking should be made part of the routine medical program.

3. Pulmonary function test (PFT) data should be kept in a format so that age-adjusted declines in function may be readily noticed on annual review of the records so that corrective action may be taken before irreversible lung pathology occurs.

\section{REFERENCES}

1. Lee AM, and Fraumeni, JF, Jr. Arsenic and Respiratory Cancer in Man: An Occupational Study. J Natl Cancer Inst 42:1045-1052, 1969.

2. Mitham S., Jr., and Strong T. Human Arsenic Exposure in Relation to a Copper Smelter. Environ Res 7:176-182, 1974.

3. Kuratsune M., Tokudome S, Shirakusa T, Yoshida M, Tokumitsu Y, Hayano $T$, and Seita M. Occupational Lung Cancer Among Smelters. Int $J$ Cancer $13: 552-558,1974$.

4. Axelson 0., Dahlgren E, Jansson CD, and Rehnlund SO. Arsenic exposure and mortality: a case referent study from a Swedish copper smelter. Brit $J$ of Ind Med 35:8-15, 1978.

5. Cordier S, Theriault G, and Iturra H. Mortality Patterns in a Population Living near a Copper Smelter. Environ Res 31:311-322, 1983.

6. Pershagen, G. The Carcinogenicity of Arsenic. Environ Health Perspectives 40:93-100, 1981 
Heal th Hazard Evaluation Report No. 84-038, Page 15

7. Landrigan P. Arsenic-State of the Art, Am J of Ind Med, 2:5-14, 1981.

8. Lauwerys RR. Industrial Chemical Exposure Guidelines for Biological Monitoring, pp. 29, Biomedical Publications, Davis CA, 1983.

9. Baselt RC. Biological Monitoring Methods for Industrial Chemicals, pp. 29-35, 159, Biomedical Publications, Davis, CA, 1980.

10 Scott R, Paterson PJ, Mills EA, Et al. Clinical and Biochemical abnormalities in coppersmiths exposed to cadmium. Lancet 1976, $2: 396-98$.

11. Webb M. Cadmium. Br Med Bu11 31:246-50, 1975.

12. Occupational Safety and Health Administration. Occupational exposure to lead--final standard. Federal Register 1978 Nov 14:53007.

13. National Institute for Occupational Safety and Health. NIOSH/OSHA Occupational Health Guidelines for Chemical Hazards. Cincinnati, Ohio: National Institute for Occupational Safety and Health, 1981. (DHHS (NIOSH) publication no. 81-123)

14. Baker EL, Hayes CG, Landrigan PJ, Handke JL, Leger RT, Housworth WJ, and Harrington JM. A nationwide survey of heavy metal absorption in children living near primary copper, lead, and zinc smelter. Am J Epidemiol 106:261-273, 1977.

\section{AUTHORSHIP AND ACKNOWLEDGMENTS}

Report Prepared By:

Bobby J. Gunter, Ph.D.

Regional Industrial Hygienist

NIOSH, Region VIII

Denver, Colorado

Paul J. Seligman, M.D.

Medical officer

Medical Section, Hazard Evaluation \&

Technical Assistance Branch

Division of Surveillance, Hazard Evaluations and Field Studies

Field Assistance

Maria E. Moll, M.D.

Medical Epidemiologist

Office of Epidemiology

State of New Mexico

Originating Office:

Hazard Evaluation and Technical Assistance Branch (HETAB)

Division of Surveillance, Hazard

Evaluations, and Field Studies (DSHEFS) NIOSH, Cincinnati, Ohio

Report Typed By:

Loraine Emerson

NIOSH, Region VIII

Denver, Colorado 
Health Hazard Evaluation Report No. 84-038, Page 16

XIII. DISTRIBUTION AND AVAILABILITY

Copies of this report are currently available upon request from NIOSH, Division of Standards Development and Technology Transfer, Information Resources and Dissemination Section, 4676 Columbia Parkway, Cincinnati, Ohio 45226. After 90 days the report will be available through the National Technical Information Service (NTIS), Springfield, Virginia. Information regarding its availability through NTIS can be obtained from NIOSH, Publications office, at the Cincinnati address.

Copies of this report have been sent to:

1. Kennecott Smelter, Hurley, New Mexico

2. United States Steel Workers Union

3. New Mexico State Health Department

4. U.S. Department Labor/OSHA - Region VIII

5. NIOSH - Region VIII

For the purpose of informing affected employees, a copy of this report shall be posted in a prominent place accessible to the employees for a period of 30 calendar days. 
Health Hazard Evaluation Report No. 84-038, Page 17

\section{TABLE I}

Breathing Zone and General Room Air Concentrations of Arsenic (As), Cadmium (Cd), Copper ( $\mathrm{Cu}$ ), and Lead (Pb)

Kennecott Smelter

Hurley, New Mexico

January $10 \& 11,1984$

\begin{tabular}{|c|c|c|c|c|c|c|c|}
\hline \multirow[b]{2}{*}{ SAMPLE $\#$} & \multirow[b]{2}{*}{$\mathrm{JOB}$} & \multirow[b]{2}{*}{ LOCATION } & \multirow[b]{2}{*}{ SAMPLING TIME } & \multicolumn{4}{|c|}{$\mathrm{mg} / \mathrm{M}^{3}$} \\
\hline & & & & As & $\mathrm{Cd}$ & $\mathrm{Cu}$ & $\mathrm{Pb}$ \\
\hline 1 & Tapper & $\begin{array}{l}\text { Reverberatory } \\
\text { Furnace }\end{array}$ & $7: 00-2: 35$ & * & * & 0.20 & 0.006 \\
\hline 2 & Feedermen & $\begin{array}{l}\text { Reverberatory } \\
\text { Furnace }\end{array}$ & $7: 05-2: 35$ & * & * & 0.30 & * \\
\hline 3 & Archblower & $\begin{array}{l}\text { Reverberatory } \\
\text { Furnace }\end{array}$ & $7: 06-2: 35$ & * & * & 0.80 & 0.006 \\
\hline 4 & $\begin{array}{l}\text { Loader } \\
\text { Operator }\end{array}$ & $\begin{array}{l}\text { Convertor } \\
\text { Aisle }\end{array}$ & $7: 10-2: 35$ & * & * & 0.50 & $\star$ \\
\hline 5 & Sk immer & Convertor & $7: 25-2: 35$ & $\star$ & $\star$ & 0.07 & $\star$ \\
\hline 6 & $\begin{array}{l}\text { Twier } \\
\text { Puncher }\end{array}$ & Convertor & $7: 26-2: 35$ & * & * & 0.11 & $\star$ \\
\hline 32 & $\begin{array}{l}\text { Crane } \\
\text { Operator }\end{array}$ & Convertor & $7: 40-2: 30$ & * & * & 0.04 & * \\
\hline 31 & $\begin{array}{l}\text { Furnace } \\
\text { Helper }\end{array}$ & Refinery & $11: 22 p m-6: 40 a m$ & * & * & 0.11 & * \\
\hline 30 & $\begin{array}{l}\text { Furnace } \\
\text { Man }\end{array}$ & Refinery & $11: 27 p m-6: 45 a m$ & * & * & 0.06 & * \\
\hline 33 & Precipitator & Sampler & $8: 02-12: 26$ & * & * & 0.76 & * \\
\hline 34 & Precipitator & Operator & $7: 53-2: 30$ & $\star$ & 0.01 & 0.45 & 0.06 \\
\hline 100 & Acid Loader & Acid Plant & $7: 12-2: 42$ & * & * & 0.05 & * \\
\hline 101 & Acid Loader & Acid Plant & $7: 15-2: 42$ & * & * & 0.08 & $\star$ \\
\hline 102 & Attendant & Acid Plant & $7: 20-2: 42$ & * & * & 0.07 & * \\
\hline 103 & General area & Acid Plant & $7: 28-2: 50$ & $\star$ & $\star$ & 0.06 & * \\
\hline Evaluati & ion Criteria & & & $.01 \mathrm{a}$ & $\mathrm{a}_{0.040}$ & 1 & 0.05 \\
\hline Laboratc & ory Limit of & letection $\mathrm{mg} / \mathrm{sam}$ & & 0.025 & 0.001 & 0.001 & 0.003 \\
\hline
\end{tabular}

* - Below Laboratory Limit of Detection

a - Based on 10-hour day 
Health Hazard Evaluation Report No. 84-038, Page 18

Table II

Breathing Zone and General Room Air Concentrations

of Sulfur Dioxide

Kennecott Smelter

Hurley, New Mexico

January 10, 1984

\begin{tabular}{|c|c|c|c|c|}
\hline SAMPLE \# & $\mathrm{JOB}$ & SAMPLE LOCATION & SAMPLING TIME & $\begin{array}{c}\mathrm{mg} / \mathrm{M}^{3} \\
\text { SULFUR DIOXIDE }\end{array}$ \\
\hline $\mathrm{So}_{2}-1$ & Tapper & $\begin{array}{l}\text { Reverberatory } \\
\text { Furnace }\end{array}$ & $7: 00-2: 35$ & 7 \\
\hline $\mathrm{So}_{2}-2$ & Feedermen & $\begin{array}{l}\text { Reverberatory } \\
\text { Furnace }\end{array}$ & $7: 05-2: 35$ & 9 \\
\hline $\mathrm{SO}_{2}-3$ & Archblower & $\begin{array}{l}\text { Reverberatory } \\
\text { Furnace }\end{array}$ & $7: 06-2: 35$ & 8 \\
\hline $\mathrm{SO}_{2}-4$ & $\begin{array}{l}\text { Loader } \\
\text { Operator }\end{array}$ & Convertor Aisle & $7: 10-2: 35$ & 0.4 \\
\hline $\mathrm{So}_{2}-5$ & Skimmer & Convertor & $7: 25-2: 35$ & 2 \\
\hline $\mathrm{SO}_{2}-6$ & $\begin{array}{l}\text { Twier } \\
\text { Puncher }\end{array}$ & Convertor & $7: 26-2: 35$ & 1.4 \\
\hline $\mathrm{So}_{2}-32$ & Craneman & Convertor & $7: 40-2: 30$ & 9 \\
\hline Evaluation & \multicolumn{3}{|l|}{ Criteria } & 1.3 \\
\hline \multicolumn{5}{|c|}{ Laboratory Limit of detection $0.010 \mathrm{mg} / \mathrm{sample}$} \\
\hline
\end{tabular}


Heal th Hazard Evaluation Report No. 84-038, Page 19

\section{TABLE II I}

General Room Air Concentrations

of Sulfuric Acid

Kennecott Smeiter

Hurley, New Mexico

January 10, 1984

\begin{tabular}{lccc}
\hline SAMPLE \# & LOCATION & SAMPLING TIME & $\begin{array}{c}\mathrm{mg} / \mathrm{M}^{3} \\
\text { SULFURIC ACID }\end{array}$ \\
\hline 200 & Acid Plant & $7: 30-2: 50$ & 0.15 \\
201 & Acid Plant & $7: 28-2: 50$ & 0.23 \\
202 & Acid Plant & $7: 28-2: 50$ & 0.24 \\
\hline Evaluation Criteria & & 1.0 \\
Laboratory Limit of Detection & $0.004 \mathrm{mg} /$ sample & \\
\hline
\end{tabular}


TABLE IV

Breathing Zone Air Concentrations of Quartz, Cristabolite and Total Particulate

Kennecott Smelter

Hurley, New Mexico

January 11, 1984

\begin{tabular}{llllccc}
$\begin{array}{l}\text { SAMPLE } \\
\#\end{array}$ & JOB & LOCATION & SAMPLING TIME & QUARTZ & $\begin{array}{c}\mathrm{mg} / \mathrm{M}^{3} \\
\text { CRISOBALITE }\end{array}$ & $\begin{array}{c}\text { TOTAL } \\
\text { PARTICULATE }\end{array}$ \\
\hline 9769 & $\begin{array}{c}\text { Tripperman } \\
\text { Furnace }\end{array}$ & Reverberatory & $11: 10 \mathrm{p}-7: 00 \mathrm{a}$ & 0.07 & $*$ & 6.9 \\
9758 & $\begin{array}{c}\text { Tripperman } \\
\text { Evaluation Criteria }\end{array}$ & Reverberatory & $11: 05 \mathrm{p}-6: 30 \mathrm{a}$ & 0.04 & $*$ & 2.6 \\
\hline $\begin{array}{l}\text { Laboratory Limits of Detection } \\
0\end{array}$ & $0.01 \mathrm{mg} / \mathrm{sample}$ & & $0.3^{\star \star}$ & $0.15^{\star \star}$ & 10.0 \\
\hline
\end{tabular}

* - Below Laboratory Limit of Detection

** - 1983-84 ACGIH Notice of Intended Changes 
Heal th Hazard Evaluation Report No. 84-038, Page 21

\section{TABLE V}

Summary of Company Medical Record Review

Kennecott Smelter

Hurley, New Mexico

\begin{tabular}{|c|c|c|c|c|}
\hline$\underline{\mathrm{Job}}$ & $\#$ & $\begin{array}{c}\text { CXR } \\
(\% \text { normal }) \\
\end{array}$ & $\begin{array}{c}\text { PFT } \\
\text { FVC/FEV }\end{array}$ & \% squamous metaplasia \\
\hline $\begin{array}{l}\text { Skimmer/ } \\
\text { Converter }\end{array}$ & 12 & 100 & $98 / 98$ & $43 \% \quad(N=7)$ \\
\hline Puncher & 16 & 100 & $97 / 96$ & $50 \% \quad(N=12)$ \\
\hline Tripperman & 3 & 100 & $100 / 94$ & $0 \% \quad(N=2)$ \\
\hline Tapper & 9 & 100 & $98 / 98$ & $0 \%(N=6)$ \\
\hline Feedermen & 8 & 88 & $101 / 99$ & $50 \% \quad(N=4)$ \\
\hline $\begin{array}{l}\text { Laborer/ } \\
\text { Boiler }\end{array}$ & 12 & 100 & $94 / 95$ & $33 \% \quad(N=3)$ \\
\hline $\begin{array}{l}\text { Smel ter } \\
\text { Equip. Op. }\end{array}$ & 3 & 100 & $95 / 94$ & $50 \%(\mathrm{~N}=2)$ \\
\hline $\begin{array}{l}\text { El ectrostatic } \\
\text { Precip. }\end{array}$ & 3 & 67 & $86 / 66$ & $33 \% \quad(N=3)$ \\
\hline
\end{tabular}




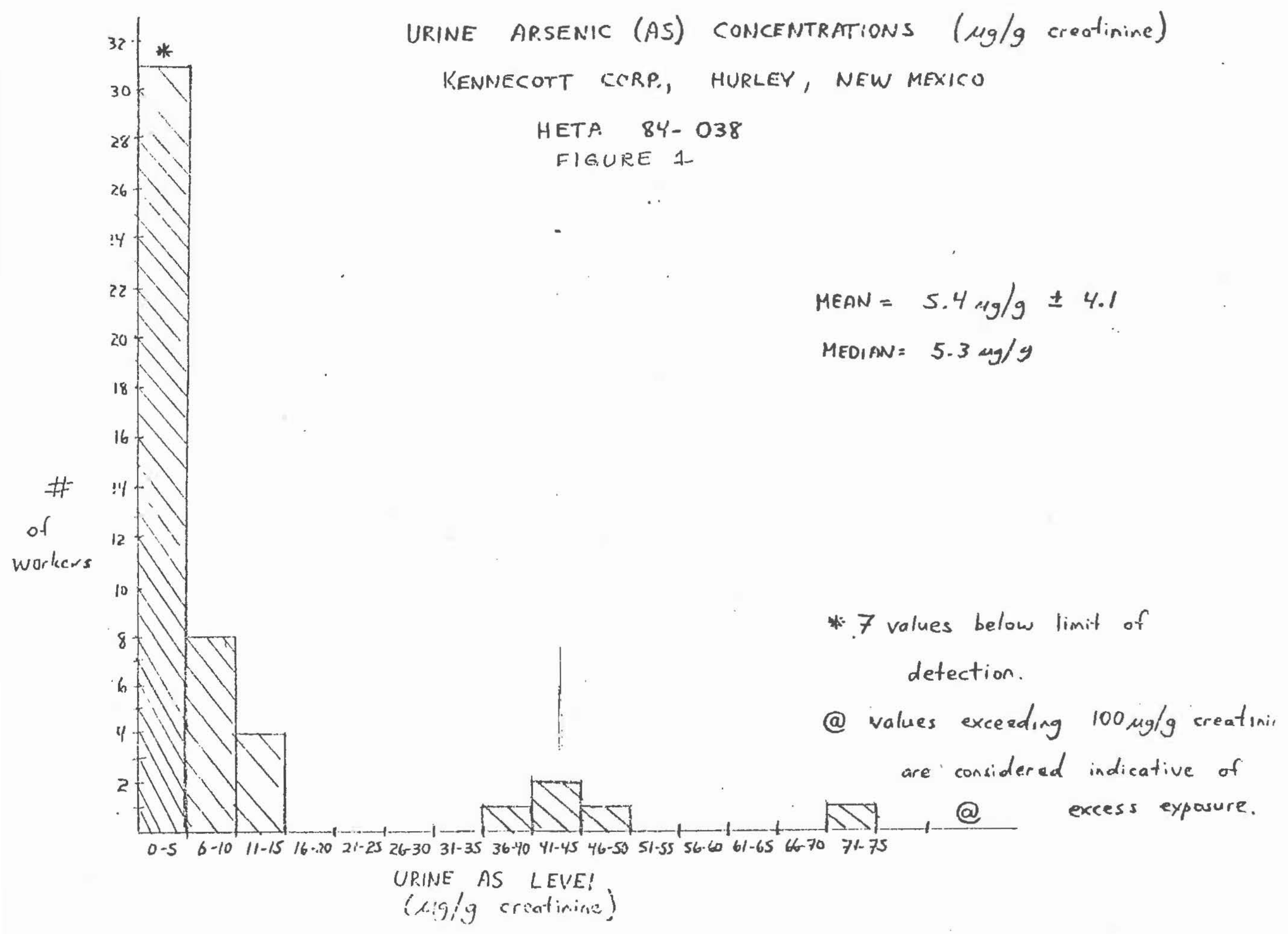


DEPARTMENT OF HEALTH AND HUMAN SERVICES

PUBLIC HEALTH SERVICE

CENTERS FOR DISEASE CONTROL

NATIONAL INSTITUTE FOR OCCUPATIONAL SAFETY ANO MEALTH

ROBERT A. TAFT LABORATORIES

4676 COLUMBIA PAAKWAY, CINCINNATI, OHIO 45226

OFFICIAL BUSINESS

PENALTY FOR PAIVATE USE, $\$ 300$
Third Class Mail

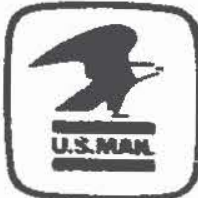

POST AGE AND FEES PAID U.S. DEPARTMENT OF HHS HIS 396 